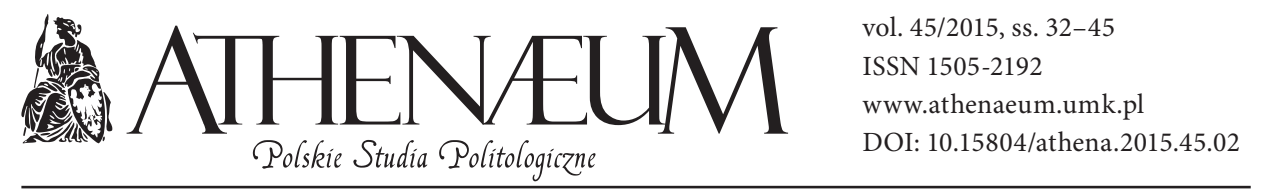

\title{
ANALIZA PORÓWNAWCZA FRAKCJI W PARTII LIBERALNO-DEMOKRATYCZNEJ ORAZ GRUP W PARTII DEMOKRATYCZNEJ PO ALTERNACJI WŁADZY W JAPONII W 2009 ROKU*
}

\author{
Karol Żakowski**
}

\begin{abstract}
COMPARATIVE ANALYSIS OF FACTIONS IN THE LIBERAL DEMOCRATIC PARTY AND GROUPS INSIDE THE DEMOCRATIC PARTY OF JAPAN AFTER ALTERNATION OF POWER IN 2009
\end{abstract}

\section{- ABSTRACT}

The article examines the changes in factional system of the Democratic Party of Japan (DPJ) after electoral victory in 2009. During opposition period, DPJ factions were believed to be much less significant groups than their counterparts in the Liberal Democratic Party (LDP). Nevertheless, after the DPJ assumed power, its intra-party groups, to a certain degree, started functioning as LDP factions. Over the years, their ideological leanings weakened and instead of realizing distinctive political vision, they started focusing on pragmatic struggle for power in the party. In 2009-2012 period, the competition between intra-party mainstreams and anti-mainstreams increased, challenging the unity of the DPJ. The significance of factional divisions was also clearly visible in the distribution of governmental portfolios by succeeding prime ministers. Although DPJ factions were still not as powerful as LDP factions, they played a much greater role than before in maintaining intra-party balance and structuring intra-party competition.

\section{- KEYWORDS}

factional divisions, Japan, Democratic Party of Japan (DPJ), Liberal Democratic Party (LDP)

* Niniejszy artykuł powstał w ramach projektu dotyczącego zmian w procesie decyzyjnym za rządów Partii Demokratycznej w Japonii. Projekt został sfinansowany ze środków Narodowego Centrum Nauki przyznanych na podstawie decyzji numer DEC-2011/01/B/HS5/00863.

** Uniwersytet Łódzki, Wydział Studiów Międzynarodowych i Politologicznych. 
Podział głównych partii politycznych na frakcje od dawna stanowił jedną z cech charakterystycznych japońskiej sceny politycznej. Frakcją (habatsu) można nazwać „krąg towarzyski związany wspólnym pochodzeniem czy interesem bądź członkostwem w partii lub grupie politycznej" ${ }^{1}$. Rządząca niemal nieprzerwanie w latach 1955-2009 Partia Liberalno-Demokratyczna (PL-D, Jiyū Minshutō) stanowiła raczej zlepek luźno związanych środowisk niż spójne ugrupowanie. Chociaż znaczenie podziałów wewnątrzpartyjnych uległo osłabieniu w latach dziewięćdziesiątych XX wieku, frakcje w PL-D przetrwały i nadal odgrywają pewną rolę, np. w rozdziale stanowisk partyjnych i państwowych czy wyborach na stanowisko przewodniczącego ugrupowania. W przeciwieństwie do PL-D Partia Demokratyczna (PD, Minshutō) posiadała znacznie mniej zinstytucjonalizowany system frakcyjny². Można w niej było wyróżnić grupy wywodzące się z mniejszych partii, które w latach 1996-2003 połączyły się, tworząc obecne ugrupowanie, ponieważ jednak do 2009 roku PD znajdowała się w opozycji, ich rola pozostawała ograniczona. Działo się tak dlatego, iż nie istniała rywalizacja międzyfrakcyjna o dostęp do stanowisk rządowych, zaś chcąc uniknąć rozłamów, PD często unikała przeprowadzania rywalizacyjnych wyborów na przewodniczącego ugrupowania. Dopiero po objęciu władzy w latach 2009-2012 pojawiły się bardziej sprzyjające warunki do upodobnienia się grup wewnątrz PD do frakcji w PL-D. Celem niniejszego artykułu jest zbadanie, na ile przejęcie władzy wpłynęło na kształt systemu frakcyjnego w PD.

W celu porównania grup wewnątrz PD i frakcji w PL-D zasadna wydaje się analiza ewolucji trzech czynników: podziałów ideologicznych, znaczenia frakcji w wyborach przewodniczącego partii oraz ich roli w rozdziale stanowisk rządowych. Zwykło się uważać, iż spoiwem frakcji w PL-D były w większym stopniu relacje interpersonalne i wspólny interes polityczny niż wyróżniki programowe ${ }^{3}$. Pomimo braku wyraźnie spisanego programu poszczególne frakcje posiadały

${ }^{1}$ K. Uchida, Habatsu. Seiken kōsō no omote to ura [Frakcje. Jawna i ukryta strona rywalizacji o władzę], Tokio 1983, s. 156.

${ }^{2}$ Obecnie w Japonii występuje system bliski dwupartyjnemu, choć po wyborach z grudnia 2012 roku pojawił się trzeci silny gracz - Stowarzyszenie Odnowy Japonii (Nippon Ishin no Kai). Zarówno PL-D, jak i PD są platformami współpracy różnorodnych środowisk i trudno jest stwierdzić, która z nich sytuuje się na prawym, a która na lewym skrzydle japońskiej sceny politycznej. Szerzej na temat japońskiego systemu partyjnego: K. Zakowski, Evolution of the Japanese Political Scene: Toward a Non-Issue-Oriented Two-Party System?, „Asian Journal of Political Science” 2011, vol. 19, nr 2, s. $186-207$.

${ }^{3}$ Ui. Kong, Ilbon hyeondae jeongchi-ui ihae [Rozumienie współczesnej polityki japońskiej], Pusan 2003, s. 137-138. 
jednak, zwłaszcza w początkowym okresie swojego istnienia, w miarę wyraźne koloryty ideologiczne, które odróżniały je od innych grup wewnątrzpartyjnych ${ }^{4}$. Pierwotnie do podstawowych funkcji frakcji należało zarządzanie funduszami na działalność polityczną oraz udzielanie wsparcia w kampaniach wyborczych, ale zadania te zanikły po zmianie ordynacji wyborczej oraz zaostrzeniu zasad finansowania partii politycznych w $1994 \mathrm{roku}^{5}$. Jedyną funkcją frakcji, która zachowała pewne znaczenie, jest rywalizacja o stanowiska partyjne i państwowe. W zamian za wsparcie udzielone liderom frakcji lub wyznaczonym przez nich kandydatom na przewodniczącego PL-D szeregowi członkowie grup wewnątrzpartyjnych mogą liczyć na pomoc swoich zwierzchników w karierze politycznej.

\section{PODZIAŁY IDEOLOGICZNE WEWNĄTRZ PARTII DEMOKRATYCZNEJ}

Jedną z cech frakcji w PL-D była ich bezprogramowość. Dawna partia dominująca została utworzona w 1955 roku z połączenia dwóch ugrupowań konserwatywnych $^{6}$ - Partii Liberalnej (PL, Jiyūtō) oraz Japońskiej Partii Demokratycznej (JPD, Nihon Minshutō). Tak naprawdę zarówno PL, jak i JPD stanowiły konglomerat środowisk wywodzących się z mniejszych ugrupowań, więc system frakcyjny PL-D początkowo obejmował osiem grup - po cztery z każdej z partii składowych. Chociaż głównym celem istnienia frakcji było dbanie o interes polityczny jej członków, a nie realizacja programu politycznego dało się zauważyć pewne różnice w kolorycie ideologicznym poszczególnych grup. Były one dziedzictwem odmienności programowych partii, które weszły w skład PL-D. Np. wywodząca się z PL frakcja Ikedy Hayato (premier w latach 1960-1964)

${ }^{4}$ K. Żakowski, Mechanizm „sztucznej zmiany władzy” w Partii Liberalno-Demokratycznej, [w:] Zmiany społeczne w Japonii w XIX i XX wieku. Wybrane zagadnienia, red. E. Kostowska-Watanabe, Kraków 2012, s. 300-307.

${ }^{5}$ Wprowadzono system dotacji budżetowych dla partii politycznych, co zwiększyło rolę centralnych organów partyjnych w przydzielaniu funduszy posłom. $Z$ kolei zastąpienie wielomandatowych okręgów wyborczych mieszanym systemem wyborczym z dominacją jednomandatowych okręgów wyeliminowało rywalizację w danym regionie pomiędzy posłami tego samego ugrupowania. Szerzej na ten temat: K. Lee, Ilbon-ui jeongdang-gwa jeongdang jeongchi [Japońskie partie i polityka partyjna], Seul 2006, s. 138-140.

${ }^{6} \mathrm{~W}$ okresie zimnowojennym obozem konserwatywnym nazywano ugrupowania popierające sojusz ze Stanami Zjednoczonymi, zaś obozem postępowym socjalistów i komunistów, którym było ideologicznie bliżej do Związku Radzieckiego. 
w dużym stopniu reprezentowała podejście prorynkowe ${ }^{7}$, zaś pochodząca z JPD frakcja Kishiego Nobusuke (premier w latach 1957-1960) w większości skupiała parlamentarzystów dążących do remilitaryzacji kraju i zwiększenia aktywności Japonii w regionalnej polityce bezpieczeństwa ${ }^{8}$. Z biegiem czasu jednak preferencje programowe poszczególnych frakcji uległy pewnemu zatarciu. Nie jest to zaskakujące, biorąc pod uwagę fakt, że ze świata polityki stopniowo odchodzili parlamentarzyści pamiętający działalność w mniejszych ugrupowaniach, które utworzyły PL-D, zaś zastępowali ich młodsi działacze, dla których głównym punktem odniesienia był program polityczny partii dominującej jako całości, a nie jej części składowych.

Analogicznie do PL-D, PD powstała w wyniku fuzji licznych mniejszych partii o różnych programach politycznych. W skład pierwotnego ugrupowania w 1996 roku weszli w większości parlamentarzyści z Partii Socjaldemokratycznej (PSD, Shakai Minshutō) oraz wywodzącej się z PL-D Nowej Partii Pionierów (NPP, Shintō Sakigake). W kolejnych latach PD rozrastała się, wchłaniając inne ugrupowania opozycyjne. W 1998 roku utworzono „nową” PD - dołączyły do niej Partia Narodowych Rządów (PNR, Minseitō), Nowa Partia Braterstwa (NPB, Shintō Yūai) oraz Demokratyczna Federacja Reform (DFR, Minshu Kaikaku Rengō). PD nabrała ostatecznego kształtu, gdy połączyła się z Partią Liberalną (PL, Jiyūtō) w 2003 roku.

Biorąc pod uwagę ugrupowania, z których wywodzą się parlamentarzyści PD, w okresie 2009-2012 można było wyróżnić trzy obozy - frakcje pochodzące z partii lewicowych, z PL-D oraz z nowych partii konserwatywnych powstałych w latach 90. XX wieku. Do pierwszego obozu należały grupy Yokomichiego Takahiro (dawna PSD), Kawabaty Tatsuo (dawna NPB, czyli wcześniejsza Demokratyczna Partia Socjalistyczna, Minshatō) oraz Kana Naoto (politycy dawnej PSD i mniejszych ugrupowań lewicowych). Wszystkie miały prosocjalne nastawienie, zaś frakcje Yokomichiego i Kawabaty były wspierane przez dwa najważniejsze dawne związki zawodowe - odpowiednio Sōhyō i Dōmei (obecnie części składowe Japońskiej Konfederacji Związków Zawodowych Rengō). O ile frakcja Yokomichiego jednak skupiała przeciwników rewizji artykułu 9 Konstytucji

\footnotetext{
7 Wielu polityków frakcji Ikedy było przywiązanych do „doktryny Yoshidy”, zgodnie z którą Japonia powinna odłożyć remilitaryzację na przyszłość i skupić się na osiągnięciu wysokiego tempa wzrostu gospodarczego. Szerzej na ten temat: K. Zakowski, Kōchikai of the Japanese Liberal Democratic Party and Its Evolution After the Cold War, ,, The Korean Journal of International Studies” 2011, vol. 9, nr 2, s. 179-205.

8 J. Honzawa, Jimintō habatsu [Frakcje PL-D], Tokio 1990, s. 112-114.
} 
Japonii ${ }^{9}$, grupa Kawabaty pod względem polityki obronności charakteryzowała się zabarwieniem prawicowym. Było to spowodowane tym, że jako reprezentant interesów robotników z branży zbrojeniowej dążyła do remilitaryzacji kraju. Do innego obozu można było zaliczyć grupy Ozawy Ichirō (dawna PL), Hatoyamy Yukio (dawna NPP i część członków innych partii konserwatywnych) oraz Haty Tsutomu (dawna PNR i część członków innych konserwatywnych ugrupowań). Frakcje te wywodziły się z PL-D, zaś pod względem ideologicznym zajmowały w PD pozycję centrową i centroprawicową. Najdalej na prawo sytuowały się grupy Maehary Seijiego i Nody Yoshihiko, których czołowi politycy rozpoczynali kariery parlamentarne w takich konserwatywnych partiach, powstałych w latach 90. XX wieku, jak Nowa Partia Japonii (NPJ, Nihon Shintō). Wielu z nich reprezentowało neoliberalny pogląd na politykę gospodarczą. Maehara Seiji należał też do najbardziej prawicowych polityków, którzy byli zwolennikami asertywnej polityki wobec zbrojących się Chin i Korei Północnej ${ }^{10}$.

Tabela 1. Usytuowanie ideologiczne frakcji w PD

\begin{tabular}{|c|c|c|c|}
\hline Frakcja & Lipiec 2003 & Wrzesień 2003 & Sierpień 2005 \\
\hline Yokomichiego & 3,1 & 3,2 & 3,6 \\
\hline Kana & 4,5 & 5,0 & 4,9 \\
\hline Haty & 5,9 & 5,4 & 5,2 \\
\hline Hatoyamy & 6,3 & 5,9 & 5,6 \\
\hline Kawabaty & 5,5 & 5,4 & 5,7 \\
\hline Ozawy & poza PD & 6,1 & 5,8 \\
\hline Maehary & 5,2 & 5,4 & 5,8 \\
\hline Nody & 6,8 & 6,7 & 6,4 \\
\hline Średnia PD & 5,2 & $\mathbf{5 , 3}$ & $\mathbf{5 , 4}$ \\
\hline Liczba parlamentarzystów & $\mathbf{9 2}$ & $\mathbf{1 6 2}$ & $\mathbf{1 6 1}$ \\
\hline
\end{tabular}

Źródło: Sh. Hamamoto, Minshutō ni okeru yakushoku haibun no seidoka [Instytucjonalizacja rozdziału stanowisk w Partii Demokratycznej], [w:] Minshutō no soshiki to seisaku [Organizacja i polityka Partii Demokratycznej], red. T. Uekami, H. Tsutsumi, Tokio 2011, s. $41^{11}$.

${ }^{9}$ Artykuł 9 Konstytucji Japonii zakazuje posiadania sił zbrojnych. Mimo to kraj ten utrzymuje nowoczesne Siły Samoobrony, które są de facto jedną z najlepszych armii konwencjonalnych na świecie.

10 E. Itagaki, Minshutō habatsu kōsōshi [Historia rywalizacji frakcji Partii Demokratycznej], Tokio 2008, s. 15-27; A. Kusano, Seiken kōtai no hōsoku [Zasada zmiany władzy], Tokio 2008, s. 158-180.

11 Sondaże przeprowadzone wśród parlamentarzystów PD, polegające na wyborze własnego usytuowania na osi „obóz postępowy” (w Japonii tradycyjne określenie lewicy) - „obóz konserwatywny" (prawica). Skala od 1 (skrajnie postępowy) do 10 (skrajnie konserwatywny). 
Jak widać, w chwili utworzenia PD poszczególne frakcje posiadały bardzo wyraźne koloryty ideologiczne - od tradycyjnej lewicy po prawicę, od obrońców pacyfistycznej konstytucji po promotorów zwiększenia wydatków na zbrojenia, od zwolenników hojnego systemu opieki społecznej po głosicieli neoliberalnych reform gospodarczych. Z drugiej strony badania przeprowadzone w latach 2003-2005 przez zespół pracowników Uniwersytetu Tokijskiego i gazety „Asahi Shinbun" wskazują na stopniowe zacieranie się wyrazistości ideologicznej członków większości frakcji. Jak widać w tabeli 1, na osiem głównych frakcji jedynie grupy Maehary i Kawabaty nie zbliżyły się w analizowanym okresie do średniej partyjnej pod względem usytuowania na osi „obóz postępowy” (lewica) - „obóz konserwatywny" (prawica) ${ }^{12}$.

Chociaż brakuje podobnych sondaży z późniejszego okresu, można przypuszczać, iż trend stopniowego zanikania kolorytu ideologicznego frakcji nie został przerwany. Świadczy o tym fakt, że podobnie jak w przypadku PL-D parlamentarzystów odchodzących na emeryturę zastępowali młodzi politycy, którzy nie pamiętali działalności w mniejszych ugrupowaniach. Dokładny skład frakcji w PD było bardzo trudno określić ze względu na to, iż nie upubliczniano list członków, zaś powszechnie występowało nieznane w PL-D zjawisko przynależności jednej osoby do wielu grup jednocześnie. Badania przeprowadzone przez profesora Uniwersytetu Kōchi Uekamiego Takayoshiego wskazują jednak na wyraźną dominację w poszczególnych grupach polityków, którzy rozpoczynali kariery parlamentarne w zjednoczonej PD. Po wyborach do Izby Reprezentantów w 2009 roku było to 19 na 42 osoby we frakcji Yokomichiego, 55 na 68 osób we frakcji Kana, 8 na 20 osób we frakcji Haty, 12 na 20 osób we frakcji Hatoyamy, 34 na 69 osób we frakcji Kawabaty, 19 na 40 osób we frakcji Ozawy, 12 na 17 osób we frakcji Maehary oraz aż 18 na 21 osób we frakcji Nody ${ }^{13}$. Z kolei analizując kariery wszystkich parlamentarzystów PD z Izby Reprezentantów w 2009 roku, zauważamy, że aż 79,2 proc. $z$ nich nigdy nie należało jako posłowie do innych partii niż PD (w 2005 roku było to 62,8 proc.) ${ }^{14}$.

Biorąc pod uwagę szybkie tempo zmiany pokoleniowej, można oczekiwać, że niedługo niemal wszyscy członkowie frakcji, być może z wyjątkiem ich ścisłego przywództwa, będą się bardziej utożsamiać z programem PD jako całości niż

12 Ibidem, s. 40-43.

13 T. Uekami, Senkyo seido kaikaku to Minshutō daihyō senshutsu katei ni okeru funsō kanri [Reforma systemu wyborczego a zarządzanie sporami w procesie wyboru przewodniczącego Partii Demokratycznej], [w:] Minshutō no soshiki..., op.cit., s. 80.

14 Sh. Hamamoto, op.cit., s. 37. 
ideologią reprezentowaną przez dawne partie składowe ugrupowania. Chociaż koloryty ideologiczne poszczególnych frakcji nie zanikły zupełnie, zmniejszający się dystans pomiędzy poglądami politycznymi członków poszczególnych grup stwarzał coraz bardziej sprzyjające okoliczności do upodobnienia się ich do frakcji występujących w PL-D. Działo się tak dlatego, że zamiast na realizacji własnej wizji politycznej grupy wewnątrzpartyjne w większym stopniu zaczęły się skupiać na pragmatycznym reprezentowaniu interesów swoich członków. Ewolucję tę najlepiej widać na przykładzie zanikającej roli różnic programowych w zawieraniu sojuszy przy okazji wyborów na stanowisko przewodniczącego PD.

\section{ROLA FRAKCJI W WYBORACH PRZEWODNICZĄCEGO PD}

Za rządów PL-D frakcje w tym ugrupowaniu zaciekle rywalizowały o stanowisko przewodniczącego partii. Utrzymywanie przez najbardziej wpływowych polityków własnych grup miało wręcz kluczowe znaczenie w wyborach na najwyższy urząd partyjny. W celu kandydowania należało zgromadzić określoną liczbę podpisów parlamentarzystów (obecnie 20, ale wcześniej nawet 50) i była ona uważana za minimalny rozmiar liczącej się frakcji. Chociaż od 2001 roku regularnie organizowano także prawybory wśród szeregowych członków partii, aż do 2009 roku większość głosów należała do parlamentarzystów. Przy okazji każdych wyborów tworzyły się swoiste sojusze pomiędzy liderami poszczególnych grup. Ci, którzy wsparli zwycięzcę, formowali „główny nurt” i uzyskiwali największe wpływy w nowym rządzie. Przegrani czasami tworzyli „przeciwny nurt", by poprzez krytykę premiera doprowadzić do jego dymisji i samemu dojść do władzy. Często jednak w celu niedopuszczenia do rozłamu uciekano się do metod pozwalających na rozładowanie sporów wewnątrzpartyjnych, np. poprzez rozdział posad rządowych proporcjonalnie do wielkości wszystkich frakcji ${ }^{15}$.

Jak podkreśla Itagaki Eiken, także w PD rywalizacja pomiędzy frakcjami zaostrzała się zwłaszcza przy okazji elekcji przewodniczącego partii ${ }^{16}$. Co ciekawe, w okresie gdy ugrupowanie znajdowało się w opozycji, unikano przeprowadzania oficjalnych wyborów, aby nie doprowadzić do eskalacji sporów międzyfrakcyjnych. Różnice ideologiczne pomiędzy poszczególnymi grupami były na tyle świeże, że zaostrzenie rywalizacji groziło rozpadem partii. Na 13 wyborów

15 H. Iseri, Habatsu saihensei [Reorganizacja frakcji], Tokio 1988, s. 85-108.

16 E. Itagaki, op.cit., s. 76-77. 
od powstania „nowej” PD w 1998 roku do objęcia przez nią władzy w 2009 roku aż 6 razy obyło się bez głosowania (zgłosił się tylko jeden kandydat), zaś prawybory wśród szeregowych członków partii zorganizowano jedynie w 2002 roku (w pozostałych przypadkach wyboru dokonali sami parlamentarzyści i ewentualnie reprezentanci regionalnych oddziałów ugrupowania $)^{17}$. W takich okolicznościach kluczowego znaczenia nabierały zakulisowe porozumienia pomiędzy liderami frakcji. Ponieważ jednak nadal wyraźne były podziały ideologiczne, zazwyczaj utrzymywano sojusze w ramach poszczególnych obozów ${ }^{18}$. Z czasem jednak solidarność obozów ideologicznych uległa osłabieniu, co umożliwiło zawiązywanie zmiennych sojuszy na wzór PL-D. Np. w 2006 roku Ozawa Ichirō został liderem ugrupowania zarówno dzięki wsparciu bliskich mu pod względem pochodzenia frakcji Hatoyamy i Haty, jak i lewicowych grup Yokomichiego i Kawabaty ${ }^{19}$.

Według posłanki PD Kikuty Makiko po utworzeniu rządu przez jej ugrupowanie wzrost roli frakcji w wyborach na stanowisko lidera partii był nieunikniony ${ }^{20}$. Ponieważ od 2009 roku udział w sprawowaniu władzy stał się wystarczająco silnym spoiwem, by nie obawiać się rozpadu ugrupowania, PD zaczęła regularnie przeprowadzać rywalizacyjne wybory na stanowisko przewodniczącego partii, czyli jednocześnie premiera. Doprowadziło to do znacznej eskalacji sporów międzyfrakcyjnych. W okresie rządów premiera Hatoyamy Yukio od września 2009 roku do czerwca 2010 roku główny nurt w PD współtworzyły grupy Hatoyamy oraz Ozawy. Ozawa Ichirō musiał zrzec się stanowiska przewodniczącego partii w maju 2009 roku z powodu skandalu korupcyjnego, w który był zamieszany jego sekretarz ${ }^{21}$. Kiedy jednak PD zwyciężyła w wyborach do Izby Reprezentantów z sierpnia 2009 roku, Ozawa został mianowany przez Hatoyamę sekretarzem

17 K. Mori-McElwain, M. Umeda, Tōshusen kaikaku to seitō shijiritsu [Reforma wyborów lidera partii a notowania partii], [w:] Seitō seiji no konmei to seiken kōtai [Poplątanie polityki partyjnej a zmiana władzy], red. N. Hiwatari, J. Saitō, Tokio 2011, s. 203.

18 Np. kandydaturę Kana Naoto (lider PD w latach 1998-1999 oraz 2002-2004) najczęściej wspierały grupy Yokomichiego i Kawabaty, kandydaturę Hatoyamy Yukio (lider PD w latach 1999-2002) grupa Haty, zaś kandydaturę Maehary Seijiego (lider PD w latach 2005-2006) grupa Nody.

19 T. Uekami, op.cit., s. 86.

20 Wywiad autora z Kikutą Makiko, Parlament Japonii, 12.04.2012.

21 Odkryto, że organizacja Rikuzankai, która zajmowała się zdobywaniem funduszy wyborczych dla Ozawy, w latach 2003-2006 otrzymała poprzez podstawione instytucje w sumie 35 mln jenów od firmy budowlanej Nishimatsu Kensetsu, prawdopodobnie w zamian za pomoc w przetargu na budowę tamy w prefekturze Iwate. Szerzej na ten temat: Minshutō seiken 100 nichi no shinsō [Prawda o 100 dniach rządów Partii Demokratycznej], red. Asahi Shinbun Seiken Shuzai Sentā, Tokio 2010, s. 258. 
generalnym partii. Licząca w szerokim rozumieniu aż ponad stu parlamentarzystów frakcja Ozawy zupełnie zdominowała proces decyzyjny ${ }^{22}$. Hatoyama Yukio był ostro krytykowany przez inne grupy za porozumienie z Ozawą, którego nadal podejrzewano o stosowanie praktyk korupcyjnych. Ostatecznie premier podał się do dymisji w czerwcu 2010 roku, po tym, jak również u niego wykryto nieprawidłowości w finansowaniu działalności politycznej²3. Jednocześnie Ozawa utracił urząd sekretarza generalnego partii.

Wybory na lidera PD z czerwca 2010 roku, przyniosły zmianę układu sił wewnątrz partii. Ozawa Ichirō próbował utrzymać kontrolę nad ugrupowaniem, wspierając kandydaturę Tarutoko Shinjiego ${ }^{24}$, który jednak przegrał z Kanem Naoto. W ten sposób w PD utworzył się nowy główny nurt współtworzony przez frakcje Kana, Maehary i Nody. Kolejną okazją dla Ozawy do odzyskania władzy stały się wybory na lidera partii we wrześniu 2010 roku (w czerwcu 2010 roku Kan został przewodniczącym PD jedynie do końca dwuletniej kadencji, rozpoczętej jeszcze w 2008 roku przez Ozawę). Tym razem zorganizowano nie tylko wybory wśród parlamentarzystów i regionalnych reprezentantów partii, ale również prawybory pośród szeregowych członków PD. Pomimo nadal ciążących na nim zarzutów korupcyjnych Ozawa Ichirō postanowił sam zgłosić swoją kandydaturę zamiast, jak dotychczas, wesprzeć innego polityka, którym mógłby sterować zza kulis. Ozawa domagał się wzięcia przez premiera odpowiedzialności za przegraną PD w wyborach do Izby Radców w lipcu 2010 roku²5. Kan Naoto zwyciężył jednak, m.in. dzięki wymierzonym w swojego rywala hasłom ukrócenia praktyk korupcyjnych. Największą przewagę uzyskał wśród szeregowych członków partii (249 do 51 głosów w 300 jednomandatowych okręgach wyborczych),

22 Rdzeń frakcji Ozawy tworzyła grupa Isshinkai, która zrzeszała bardziej doświadczonych parlamentarzystów, zwłaszcza tych, którzy przed 2003 rokiem należeli do PL. Po wyborach w 2009 roku jednak frakcja Ozawy powiększyła się o wielu młodych posłów, którzy po raz pierwszy uzyskali mandaty. Nie zostali przyjęci bezpośrednio do Isshinkai, ale pozostawali lojalni wobec Ozawy. W szerokim rozumieniu jego frakcja mogła liczyć nawet 150 osób. Szerzej na ten temat: D. Liu, Jiushan Youjifu. Riben Minzhudang zhengzhi de kaimu [Hatoyama Yukio. Początek władzy japońskiej Partii Demokratycznej], Pekin 2009, s. 106.

${ }^{23}$ Jeszcze w 2009 roku wyszło na jaw, że nielegalne dotacje przekazywała Hatoyamie jego matka - dziedziczka fortuny założyciela firmy Bridgestone.

24 Po wyborach Tarutoko Shinji utworzył własną grupę, która posiadała pewne cechy frakcji. W niniejszym opracowaniu pominięto jednak tematykę grup wewnątrz PD utworzonych po alternacji władzy w 2009 roku ze względu na ich relatywnie niewielkie rozmiary oraz krótki okres istnienia.

${ }^{25}$ Izba Radców jest izbą wyższą japońskiego parlamentu. Co trzy lata wybiera się połowę jej składu na sześcioletnią kadencję. W wyniku wyborów z 2010 roku koalicja utraciła większość w Izbie Radców, co bardzo utrudniło rządowi proces decyzyjny. 
mniejszą pośród działaczy regionalnych (60 do 40 głosów), zaś tylko minimalną wśród parlamentarzystów (412 do 400 - głos każdego parlamentarzysty liczył się podwójnie $)^{26}$.

Kolejna odsłona rywalizacji pomiędzy głównym a przeciwnym nurtem rozpoczęła się zaledwie kilka tygodni po tragicznym trzęsieniu ziemi i fali tsunami, które 11 marca 2011 roku spustoszyły północno-wschodnie regiony Japonii. Tuż po kataklizmie frakcje Ozawy i Hatoyamy stonowały krytykę wobec premiera, jednak wznowiły ją z nową siłą w kwietniu 2011 roku. Oskarżając premiera Kana Naoto o nieudolność w walce $\mathrm{z}$ awarią $\mathrm{w}$ elektrowni atomowej w Fukushimie, politycy przeciwnego nurtu posunęli się nawet do groźby wsparcia zgłoszonego przez opozycję wniosku o wotum nieufności wobec rządu. Ostatecznie przeciwnicy premiera w PD zagłosowali przeciw wnioskowi, ale tylko dlatego, że na początku czerwca 2011 roku Kan Naoto obiecał, iż sam poda się do dymisji, gdy tylko uda mu się przezwyciężyć sytuację kryzysową związaną z następstwami marcowego trzęsienia ziemi. Premier dotrzymał słowa i złożył rezygnację w sierpniu 2011 roku. W wyborach na nowego lidera partii, zorganizowanych pośród parlamentarzystów $\mathrm{PD}$, rywalizowało aż pięciu kandydatów, w tym dwóch reprezentantów głównego nurtu - Noda Yoshihiko i Maehara Seiji. Chociaż w pierwszej turze zwyciężył kandydat wspierany przez Ozawę - Kaieda Banri z frakcji Hatoyamy - w drugiej turze został on pokonany stosunkiem głosów 215 do 177 przez Nodę Yoshihiko ${ }^{27}$.W ten sposób poprzedni główny nurt utrzymał władzę.

Jak widać, w czasach opozycyjnych PD unikała rywalizacyjnych wyborów na lidera ugrupowania, jednak zaczęła je regularnie organizować po objęciu władzy. Nie bez znaczenia pozostaje fakt, że partii rządzącej nie wypadało ustalać przewodniczącego ugrupowania, a jednocześnie premiera, poprzez zakulisowe pertraktacje między szefami frakcji. Organizowanie oficjalnych wyborów wśród parlamentarzystów, a nawet prawyborów pośród szeregowych członków partii nie zanegowało jednak roli frakcji w tym procesie. Wszyscy trzej pierwsi premierzy z ramienia PD byli jednocześnie liderami frakcji i to głównie sojuszom z szefami innych grup zawdzięczali dojście do władzy. „Demokratyzacja” wyborów przyniosła natomiast skutek uboczny w postaci wyjścia na światło dzienne i zaostrzenia rywalizacji międzyfrakcyjnej. Zaciekła walka pomiędzy

${ }^{26}$ Yomiuri Shinbun Seijibu, Bōkoku no saishō - Kantei kinō teishi no 180 nichi [Premier upadłego kraju - 180 dni wstrzymania funkcji pałacu], Tokio 2011, s. 22-24.

27 Ibidem, s. 10-184. 
głównym i przeciwnym nurtem w partii przypominała spory między frakcjami PL-D w okresie jej dominacji. Co istotne, wyraźnie widać, że w formowaniu sojuszy coraz mniejszą rolę odgrywał koloryt ideologiczny poszczególnych grup - świadczy o tym np. stworzenie głównego nurtu przez lewicową grupę Kana razem z najbardziej prawicowymi grupami Maehary i Nody.

\section{ZNACZENIE FRAKCJI PD \\ W ROZDZIALE STANOWISK RZĄDOWYCH}

Jak wspomniano, w ramach systemu frakcyjnego PL-D nowy przewodniczący partii po objęciu urzędu premiera mógł zastosować jedną z dwóch metod „podziału łupów” - pominąć przy formowaniu rządu przedstawicieli frakcji przeciwnego nurtu lub rozdzielić stanowiska ministerialne proporcjonalnie do wielkości wszystkich grup. Początkowo dominował pierwszy sposób, jednak od początku lat 80. XX wieku instytucjonalizacji uległ „ogólny główny nurt”, w ramach którego każda frakcja mogła liczyć na udział w sprawowaniu władzy. Powszechną praktyką stało się przyjmowanie przez premiera rekomendacji na stanowiska ministerialne od liderów wszystkich grup wewnątrzpartyjnych ${ }^{28}$. Praktyka ta została zanegowana przez premiera Koizumiego Jun’ichirō, który w latach 2001-2006 demonstracyjnie nominował członków własnego gabinetu, biorąc pod uwagę ich zdolności, a nie starszeństwo czy przynależność frakcyjną ${ }^{29}$. Za kadencji kolejnych szefów rządu PL-D w dużym stopniu powróciła jednak do tradycyjnych mechanizmów sprawowania władzy.

Tabela 2. Rozdział posad ministra pomiędzy frakcje PD w latach 2009-201130

\begin{tabular}{|c|c|c|c|}
\hline Frakcja & Rząd Hatoyamy & Rząd Kana & Rząd Nody \\
\hline Yokomichiego & 2 & 1 & 1 \\
\hline Kana & 2 & 2 & 1 \\
\hline Haty & 1 & 2 & 1 \\
\hline Hatoyamy & 3 & 2 & 0 \\
\hline
\end{tabular}

${ }^{28}$ H. Iseri, op.cit., s. 117-121.

29 Y. Uchiyama, Koizumi seiken [Rządy Koizumiego], Tokio 2007, s. 14-16.

30 Skład rządu Hatoyamy we wrześniu 2009 roku, Kana we wrześniu 2010 roku i Nody we wrześniu 2011 roku. Kategoria „inne” obejmuje ministrów z mniejszych partii koalicyjnych, specjalistów spoza PD, posłów bezfrakcyjnych oraz reprezentantów mniejszych, nowo powstałych grup w PD. 


\begin{tabular}{|c|c|c|c|}
\hline Frakcja & Rząd Hatoyamy & Rząd Kana & Rząd Nody \\
\hline Kawabaty & 3 & 2 & 1 \\
\hline Ozawy & 2 & 0 & 2 \\
\hline Maehary & 2 & 2 & 4 \\
\hline Nody & 0 & 2 & 1 \\
\hline Inne & 2 & 4 & 7 \\
\hline Razem & $\mathbf{1 7}$ & $\mathbf{1 7}$ & $\mathbf{1 8}$ \\
\hline
\end{tabular}

Źródło: opracowanie własne na podstawie m.in.: Sh. Hamamoto, op.cit., s. 41.

Do 2009 roku PD pozostawała w opozycji, więc nie da się zbadać wpływu jej systemu frakcyjnego na rozdział posad rządowych. $Z$ drugiej strony widać wyraźną rolę frakcji w przydzielaniu stanowisk partyjnych. Jak wykazał Hamamoto Shinsuke, o ile posady niższego szczebla były przyznawane raczej według starszeństwa i uzdolnień, o tyle najwyższe stanowiska, takie jak wiceprezes ugrupowania czy przewodniczący Rady Badań Politycznych, rozdzielano zgodnie z kluczem frakcyjnym ${ }^{31}$. Zazwyczaj dbano przy tym o równomierny podział stanowisk. Jedynie w kilku przypadkach (główny nurt Kana w 1999 roku, Hatoyamy w 2002 roku oraz Maehary w 2005 roku) widać dominację członków zwycięskich frakcji na najwyższych urzędach partyjnych.

Po 2009 roku przynależność frakcyjna miała wpływ również na rozdział stanowisk rządowych. Tabela 2 przedstawia liczbę posad ministra przypadających na każdą grupę po objęciu władzy przez trzech kolejnych premierów z PD (skład rządu Kana poddano analizie po rekonstrukcji z września 2010 roku, gdyż wcześniej Kan Naoto przejął niemal bez zmian gabinet Hatoyamy). Widać, że w 2009 roku zachowano względną równowagę w rozdziale stanowisk ministra pomiędzy poszczególne grupy. Jedynie frakcja Nody nie otrzymała teki ministerialnej, jednak można to wytłumaczyć stosunkowo małym rozmiarem tej grupy oraz przyznaniem jej relatywnie dużej liczby stanowisk wiceministra ${ }^{32}$. Nieco inny wzorzec można zauważyć, analizując skład gabinetu Kana. Niemal wszystkie frakcje oprócz grupy Ozawy otrzymały w nim równo po dwie posady ministra. Odmienne potraktowanie najliczniejszej frakcji wskazuje na celowe odsunięcie od władzy czołowej grupy przeciwnego nurtu po zaciekłej rywaliza-

31 Sh. Hamamoto, op.cit., s. 47-56.

${ }^{32}$ Frakcja Nody otrzymała aż 4 posady wiceministra, podczas gdy większość pozostałych grup od 1 do 3 stanowisk tego szczebla. Zob. ibidem, s. 57. 
cji pomiędzy Kanem Naoto a Ozawą Ichirō w wyborach na przewodniczącego partii. Dla odmiany Noda Yoshihiko zadeklarował we wrześniu 2011 roku, że jego gabinet będzie rządem „harmonii partyjnej” 33 i zadbał o silną reprezentację w rządzie przegranej frakcji Ozawy ${ }^{34}$. Z drugiej strony ani jednego stanowiska ministra nie otrzymała frakcja Hatoyamy, zaś aż cztery teki dostała sojusznicza dla Nody frakcja Maehary. Może to wskazywać na „retorsje” wobec głównego konkurenta $\mathrm{z}$ wyborów na przewodniczącego PD (Kaieda Banri należał do grupy Hatoyamy).

Nie da się zlekceważyć wpływu frakcyjność w PD na rozdział stanowisk partyjnych i państwowych. Podobnie jak szefowie rządu z PL-D, premierzy wywodzący się z nowej partii rządzącej stosowali dwie metody "podziału łupów" po wyborach na stanowisko lidera ugrupowania - równomierny rozdział posad ministerialnych pomiędzy wszystkie grupy w celu uśmierzenia sporów wewnątrzpartyjnych, jak w przypadku gabinetu Hatoyamy, lub odsunięcie od władzy politycznych konkurentów, najlepiej widoczne na przykładzie rządu Kana.

\section{WNIOSKI}

Politycy PD często unikają tematyki frakcyjności, gdyż nie chcą być kojarzeni z metodami sprawowania władzy charakterystycznymi dla dawnej partii dominującej. W latach 2009-2012 pomiędzy frakcjami w PD i PL-D nadal istniały pewne różnice - np. w pierwszych $\mathrm{z}$ nich powszechnym zjawiskiem była niespotykana w PL-D przynależność do więcej niż jednej grupy. Nie da się jednak zaprzeczyć, że historyczna alternacja władzy w 2009 roku zadziałała niczym katalizator przemian w systemie frakcyjnym PD, w dużym stopniu nadając mu charakter znany z PL-D. Chociaż początkowo poszczególne grupy stanowiły zwykłą kontynuację partii składowych PD, z czasem ich koloryt ideologiczny uległ znacznemu osłabieniu. Dzięki temu zamiast na dążeniu do realizacji własnych wizji programowych frakcje mogły się w większym stopniu skupić na reprezentacji interesów politycznych swoich członków. Liderzy frakcji wykorzystywali podwładnych do zwiększenia własnych szans w rywalizacji

33 Yomiuri Shinbun Seijibu, op.cit., s. 13.

34 Ostatecznie jednak Ozawa Ichirō opuścił PD na czele niemal 50 posłów na przełomie czerwca i lipca 2012 roku w proteście przeciw podwyżce VAT wprowadzonej przez rząd. 
o fotel przewodniczącego ugrupowania, zaś szeregowi parlamentarzyści liczyli na wsparcie bossów w uzyskaniu stanowisk partyjnych i państwowych. Jawna walka pomiędzy głównym a przeciwnym nurtem za kadencji Kana Naoto pokazała, że pod względem podziałów wewnątrzpartyjnych PD niewiele różniła się od dawnej partii dominującej. 